\title{
Sistem Pakar Deteksi Awal Covid-19 Menggunakan Metode Certainty Factor
}

\author{
Aulia Rahman Fahindra ${ }^{1, *}$, Imam Husni Al Amin² \\ 1,2 Teknologi Informasi, Universitas Stikubank, Semarang, Indonesia \\ Jl. Trilomba Juang No 1 Semarang 50241, Kota Semarang, Jawa Tengah \\ Email : ${ }^{*}$ ulickf@gmail.com, ${ }^{2}$ imam@edu.unisbank.ac.id
}

\begin{abstract}
Abstrak-Virus corona 2019 ( corona virus disease/COVID-19) merupakan virus baru yang muncul di Wuhan, China pada akhir tahun 2019. Covid-19 melanda banyak Negara di dunia termasuk Indonesia. Wabah Covid-19 tidak hanya merupakan masalah nasional dalam suatu negara, tapi sudah merupakan masalah global, covid-19 berdampak kepada kehidupan sosial dan melemahnya ekonomi masyarakat. Gejala umum yang ditimbulkan dari covid-19 adalah suhu tubuh naik, demam, mati rasa, batuk, nyeri di tenggorokan, kepala pusing, susah bernafas jika virus corona sudah sampai paru-paru. Untuk mengetahui seseorang terjangkit covid-19 pun cukup sulit karena memiliki gejala yang mirip dengan beberapa penyakit lainnya. Deteksi Covid-19 merupakan tahapan penting untuk mengenali secara dini pasien terduga Covid-19 sehingga dapat dilakukan langkah lanjutan. Salah satu cara pendeteksian adalah dengan sistem pendeteksi awal covid-19. Dengan keadaan tersebut tentunya dibutuhkan sistem pakar yang dapat melakukan sebuah deteksi awal terhadap gejala covid-19. Namun demikian dibutuhkan sebuah metode untuk mengakomodasi faktor-faktor yang ada, sehingga di dapat hasil yang akurat. Sistem pakar adalah sistem yang berusaha mengadopsi pengetahuan manusia ke komputer yang dirancang untuk memodelkan kemampuan menyelesaikan masalah seperti layaknya seorang pakar. Dengan sistem pakar ini, orang awam pun dapat menyelesaikan masalahnya atau hanya sekedar mencari suatu informasi berkualitas yang sebenarnya hanya dapat diperoleh dengan bantuan para ahli dibidangnya. Sistem pakar ini juga dapat mambantu aktivitas para pakar sebagai asisten yang berpengalaman dan mempunyai pengetahuan yang dibutuhkan. Pada prakteknya sistem pakar dalam menghadapi suatu masalah yaitu sering kali menemukan jawaban yang tidak memiliki kepastian penuh. Ketidakpastian ini bisa berupa probabilitas yang bergantung pada hasil dari suatu peristiwa. Metode Certainty Factor dipilih untuk mengakomodasi faktor ketidakpastian untuk diubah menjadi faktor kepastian, certainty factor juga dapat menyatakan kepercayaan dalam sebuah kejadian ( fakta atau hipotesa ) berdasar bukti atau laporan pakar dengan menggunakan suatu nilai untuk mengasumsikan derajat keyakinan seorang pakar terhadap suatu data. Hasil Penelitian dapat membantu masyarakat untuk melakukan diagnosa mandiri, dan paramedis untuk melakukan diagnosa awal kepada pasien, sehingga dapat mempermudah semua pihak dalam menangani Covid-19.
\end{abstract}

\section{Kata Kunci : Covid-19, Deteksi covid-19, Deteksi awal covid-19, Certainty Factor, Sistem Pakar}

Abstract-Coronavirus 2019 (corona virus disease/COVID-19) is a new virus that appeared in Wuhan, China at the end of 2019.Covid-19 has hit many countries in the world including Indonesia. The Covid-19 outbreak is not only a national problem in a country, but is already a global problem, covid-19 has an impact on social life and weakening people's economy. Common symptoms caused by covid-19 are rising body temperature, fever, numbness, cough, pain in the throat, headache, difficulty breathing if the coronavirus has reached the lungs. To know someone has covid-19 is quite difficult because they have symptoms similar to some other diseases. Covid-19 detection is an important stage to early recognize Covid-19 patients so that further steps can be taken. One way of detection is with the initial covid-19 detection system. With this condition, of course, an expert system is needed that can conduct an early detection of the symptoms of covid-19. Nevertheless it takes a method to accommodate the existing factors, so that in can accurate results. An expert system is a system that seeks to adopt human to computer knowledge designed to model problem-solving skills like an expert. With this expert system, ordinary people can solve the problem or just look for quality information that can only be obtained with the help of experts in their field. This expert system can also help the activities of experts as experienced assistants and have the necessary knowledge.In practice the expert system in dealing with a problem that is often found an answer that does not have full certainty. This uncertainty can be a probability that depends on the outcome of an event. Certainty Factor method is chosen to accommodate uncertainty factor to be converted into certainty factor, certainty factor can also express confidence in an event (fact or hypothesis) based on evidence or expert report by using a value to assume an expert's degree of confidence in a data.The results of the study can help the public to self-diagnose, and paramedics to make early diagnosis to patients, so as to facilitate all parties in handling Covid-19.

Keywords : Covid-19, Covid-19 Detection, Early detection of covid-19, Certainty Factor, Expert System 


\section{PENDAHULUAN}

Covid-19 merupakan virus baru yang muncul di Wuhan, China pada akhir tahun 2019. Virus ini dapat menular hanya dengan kontak fisik secara langsung maupun secara tidak langsung, untuk mendeteksi virus ini sangat sulit karena gejala yang ditimbulkan mirip dengan beberapa penyakit lainnya [1]. Sampai bulan November 2020 dilaporkan sudah ada 50,1 Juta kasus Positif (Terkonfirmasi) diseluruh dunia, untuk kasus di Indonesia sudah mencapai angka 438 ribu kasus, 363 ribu orang sembuh, dan 14 ribu orang meninggal dunia, dengan data tersebut tercatat angka kematian akibat covid-19 di Indonesia mencapai 4-5\% hal ini kebanyakan disebabkan oleh ketidaktahuan masyarakat mengenai gejala covid-19 dan ketakutan masyarakat untuk melakukan test covid-19 di rumah sakit. Adapun gejala umum yang ditimbulkan dari covid-19 adalah suhu tubuh naik, demam, batuk, nyeri di tenggorokan, susah bernafas jika virus corona sudah sampai paru-paru, serta didukung dengan beberapa kondisi antara lainnya seperti pernah keluar rumah dalam jangka waktu 14 hari, keluar rumah tanpa menggunakan masker [2]. Gejala klinis yang paling umum saat ini adalah demam dan batuk selain gejala non spesifik lainnya gejala termasuk dispnea, sakit kepala, nyeri otot, dan kelelahan [3]. Organisasi Kesehatan Dunia menyatakan darurat kesehatan global pada 30 Januari 2020. Berdasarkan data perkembangan kasus Covid-19 secara global maupun di Indonesia dan prediksi peningkatan jumlah kasus, tentunya perlu dilakukan beberapa langkah dalam menangani Covid-19, masyarakat harus menerapkan physical distancing dan menjaga kebersihan diri serta lingkungan sekitar sebagai langkah preventif untuk menekan penyebaran Covid-19 [4]. Hal ini sesuai dengan himbauan WHO terkait langkah strategis dalam menangani pandemi global Covid-19 [5]. Seperti halnya di negara-negara lain, suspect Corona (orang yang menunjukkan gejala terinfeksi COVID-19 dan diduga pernah melakukan kontak dengan pasien positif COVID-19) semakin meningkat di Indonesia sehingga permintaan uji spesimen pada laboratorium yang telah ditunjuk oleh pemerintah juga meningkat. Untuk itu diperlukan cara lain untuk melakukan pendeteksian COVID-19 yang lebih praktis dan cepat [6].

Ketersediaan dokter ahli dan tenaga medis covid relatif masih kurang khususnya di daerah-daerah pelosok dan terpencil, dan sulitnya mendiagnosa gejala dari virus ini, serta mahalnya melakukan rapid test maupun swab test. Hal ini membuat beberapa masyarakat kalangan menengah ke bawah kesulitan untuk melakukan test untuk mendiagnosa covid-19 sehingga penanganan medis menjadi terlambat dan dapat mengakibatkan resiko kematian. Untuk menangani faktor ketidakpastian dalam mendiagnosa gejala covid-19 maka sistem pakar dirancang dengan menggunakan teori-teori ketidakpastian seperti yang akan di bahas pada bab selanjutnya. Sistem pakar yang akan dibangun dalam penelitian ini menggunakan Certainty Factor untuk penanganan masalah ketidakpastian.

Profesor Edward Feigenbaum dan Universitas Stanford yang merupakan pelopor dalam teknologi sistem pakar mendefinisikan sistem pakar sebagai program komputer pintar yang memanfaatkan pengetahuan dan prosedur inferensi untuk memecahkan masalah yang cukup sulit [7]. Sistem pakar adalah program komputer berasal dari cabang penelitian ilmu komputer disebut Artificial Intelligence (AI). Sistem pakar digunakan untuk memecahkan sejumlah besar masalah seperti pengambilan keputusan. Sistem berbasis komputer menggunakan pengetahuan, fakta dan teknik penalaran untuk seorang ahli menyelesaikan masalah [8]. Dengan sistem pakar ini, orang awam pun dapat menyelesaikan masalahnya atau hanya sekedar mencari suatu informasi berkualitas yang sebenarnya hanya dapat diperoleh dengan bantuan para ahli dibidangnya. Sistem pakar ini juga dapat mambantu aktvitas para pakar sebagai asisten yang berpengalaman dan mempunyai pengetahuan yang dibutuhkan. Dalam hal pemecahan suatu masalah yang bersifat pengetahuan atau sistem yang dirancang khusus sebagai suatu sarana untuk melakukan konsultasi sebagai mana layaknya seorang pakar atau suatu sistem informasi menjadi suatu keharusan, disebabkan komputer adalah suatu fasilitas pendukung dalam melakukan suatu analisa terhadap banyak hal, baik dalam hal penelitian maupun seorang ahli dalam suatu bidang tertentu. Sistem pakar dalam menghadapi suatu masalah sering kali menemukan jawaban yang tidak memiliki kepastian penuh. Ketidakpastian ini bisa berupa probabilitas yang bergantung pada hasil dari suatu peristiwa. Maka dari itu dibutuhkan suatu metode yang tepat untuk mengakomodasi ketidakpastian tersebut.

Model Certainty Factor (CF) merupakan salah satu metode pengelolaan ketidakpastian dalam sistem. Shortliffe dan Buchanan mengembangkan model CF pada pertengahan 1970-an untuk MYCIN, sistem pakar untuk diagnosis dan pengobatan meningitis dan infeksi darah. Sejak itu, model CF telah menjadi pendekatan standar untuk manajemen ketidakpastian berbasis aturan sistem [9]. Certainty Factor dapat menyatakan suatu kepercayaan dalam sebuah kejadian (fakta atau hipotesa) berdasar bukti atau penilaian pakar. Certainty Factor menggunakan suatu nilai untuk mengasumsikan derajat keyakinan seorang pakar terhadap suatu data. Metode Certainty Factor memiliki kelebihan yaitu pada perhitungan dengan metode ini hanya dapat mengelola dua data saja dalam sekali hitung sehingga keakuratan data dapat terjaga [10]. Tujuan dari penelitian ini adalah membangun sistem pakar berbasis web mobile untuk mendiagnosa covid-19 berdasarkan gejala yang dinputkan oleh user, menerapkan sistem untuk mengatasi ketidakpastian dan memberikan nilai probabilitas kemungkinan pada hasil diagnosa. 
Berdasarkan permasalahan yang ada diperlukan sistem yang dapat mengatasi permasalahan tersebut dengan sebuah sistem pakar yang berbasis web mobile menggunakan suatu metode yang dapat melakukan sebuah deteksi awal terhadap gejala yang ada. Penelitian ini menggunakan metode Certainty Factor sebagai metode pendukung keputusan. Diharapkan sistem ini dapat membantu masyarakat untuk dapat melakukan test covid-19 secara mandiri di rumah, dan dapat memudahkan paramedis untuk menangani pasien covid-19.

Pada penelitian ini menggunakan metode Certainty Factor karena dianggap dapat mengakomodasi ketidakpastian pemikiran masyarakat dan pakar terhadap gejala covid-19. Selain itu bisa juga dipakai untuk mengukur suatu nilai ketidakpastian menjadi suatu nilai yang dapat digunakan untuk mendiagnosis penyakit.

\section{METODE PENELITIAN}

\subsection{Certainty Factor}

Certainty Factor merupakan metode untuk menampung pernyataan-pernyataan dari seorang ahli dalam penyampaiannya. Hasil analisis mendeskripsikan tingkat kepercayaan ahli terhadap masalah yang dihadapi. Certainty Factor berfungsi untuk mengakomodasi ketidakpastian pemikiran (inexact reasoning) seorang pakar. Certainty Factor menyatakan kepercayaan dalam sebuah kejadian (fakta atau hipotesa) berdasar bukti atau penilaian pakar [11]. Certainty Factor digunakan untuk menyatakan seberapa akurat, jujur, atau dapat diandalkan dalam menilai suatu predikat. Certainty factor menggunakan suatu nilai untuk mengasumsikan derajat keyakinan seorang pakar terhadap suatu data. Metode certainty factor digunakan untuk menghadapi suatu masalah yang jawabannya tidak pasti. Ketidakpastian ini bisa merupakan probabilitas. Certainty Factor menggunakan suatu nilai untuk mengansumsikan derajat keyakinan seorang pakar terhadap suatu data [12].

Metode Certainty Factor memiliki kelebihan yaitu pada perhitungan dengan metode ini hanya dapat mengelola dua data saja dalam sekali hitung sehingga keakuratan data dapat terjaga. Metode Certainty Factor cocok dipakai dalam sistem pakar untuk mengukur sesuatu apakah pasti atau tidak pasti dalam mendiagnosa penyakit sebagai salah satu contohnya [13].

Suatu sistem pakar seringkali memiliki kaidah lebih dari satu dan terdiri dari beberapa premis yang dihubungkan dengan AND atau OR. Pengetahuan mengenai premis dapat juga tidak pasti, hal ini dikarenakan besarnya nilai (value) CF yang diberikan oleh pasien saat menjawab pertanyaan sistem atas premis (gejala) yang dialami pasien atau dapat juga dari nilai CF hipotesa. Formula CF untuk beberapa kaidah yang mengarah pada hipotesa yang sama [14].

Perhitungan Certainty Factor dari setiap masukan gejala pengguna. Kelas yang dipilih dari proses klasifikasi adalah implementasi dari Certainty Factor untuk menemukan nilai kepastian. Proses ini diulangi masing-masing dari dua gejala masukan menggunakan rumus berikut :

$$
C F[H, E]=C F[H\} * C F[E]
$$

Informasi :

$\mathrm{CF}[\mathrm{H}, \mathrm{E}]$ : Certainty Factor dalam hipotesa (H) yang dipengaruhi oleh Fakta (E)

$\mathrm{H}$ : Hipotesa atau asumsi awal terhadap gejala

E : Evidence atau fakta dan peristiwa yang dialami user terhadap gejala

Selanjutnya adalah melakukan kombinasi nilai CF dari masing-masing gejala. Dengan Rumus sebagai berikut :

$$
\begin{aligned}
& \text { CF Combine }[H, E]_{1,2}=C F[H, E]_{1}+C F[H, E]_{2} *\left(1-C F[H, E]_{1}\right) \\
& \text { CF Combine }[H, E]_{\text {old }, 3}=C F[H, E]_{\text {old }}+C F[H, E]_{3} *\left(1-C F[H, E]_{\text {old }}\right)
\end{aligned}
$$

Informasi :

CF Combine $[\mathrm{H}, \mathrm{E}]_{1,2}$ : Kombinasi dari $\mathrm{CF}[\mathrm{H}, \mathrm{E}]_{1}$ dan $\mathrm{CF}[\mathrm{H}, \mathrm{E}]_{2}$

CF Combine $[\mathrm{H}, \mathrm{E}]_{\mathrm{old}, 3}$ : Kombinasi dari perhitungan $\mathrm{CF}[\mathrm{H}, \mathrm{E}]_{\mathrm{old}}$ atau $\mathrm{CF}[\mathrm{H}, \mathrm{R}]_{1,2}$ dengan $\mathrm{CF}[\mathrm{H}, \mathrm{E}]_{3}$

Perhitungan Kombinasi antar CF ini akan terus dilakukan sampai gejala yang diinputkan oleh user berakhir. Setelah melakukan kombinasi antar CF dan menemukan nilai keyakinan, berikutnya adalah mengubah nilai keyakinan menjadi presentase keyakinan dengan rumus : 


$$
C F=C F_{\text {old } n} * 100 \%
$$

Informasi :

$\mathrm{CF}_{\text {old } \mathrm{n}}$ : $\mathrm{CF}$ Combine terakhir dari kemungkinan gejala yang ada.

\subsection{Deskripsi Sistem}

Sistem Pakar berbasis web mobile untuk melakukan deteksi awal terhadap virus covid-19 menggunakan metode Certainty Factor. Sistem ini memungkinkan untuk melakukan deteksi awal gejala covid-19 terhadap user. Sistem ini memiliki 2 hak akses yaitu user dan admin, user dapat melakukan diagnosa mandiri dengan menginputkan gejala yang dipilih dan dialami oleh user. Sedangkan untuk admin dapat melakukan input gejala.

Dalam implementasinya sistem ini menggunakan metode certainty factor dengan beberapa tahapan, yaitu tahapan pengumpulan data, pada tahap ini peneliti melakukan penelitian dan mengambil sampel data dari rumah sakit rujukan covid-19 di Semarang untuk mendapatkan data gejala dan sekaligus untuk mendapatkan nilai hipotesa dari pakar, tahap selanjutnya adalah melakukan perhitungan dengan menggunakan certainty factor yaitu dengan menghitung setiap bobot pada gejala untuk didapatkan nilai CF-nya selanjutnya menghitung CF Combine nya untuk nantinya didapat persentase keyakinan guna mendiagnosa pasien.

Pada sistem yang akan dibangun dilakukan identifikasi terhadap pengguna yang terlibat dalam sistem pakar tersebut. Selain mengidentifikasi user, peneliti juga menjelaskan hal-hal yang dapat dilakukan oleh user. Sistem juga menggambarkan hal-hal yang dapat dilakukan oleh admin, mulai dari identifikasi data masukan, pengolahan data dan data keluaran yang dihasilkan dari sistem yang dibangun. Dalam pengolahan data dan pengambilan keputusan diagnosa covid-19.

Proses User diawali dengan melakukan login, jika belum memiliki akun, user dapat melakukan registrasi terlebih dahulu, setelah login user dapat masuk ke halaman utama yang berisi beberapa menu seperti Input Gejala, Solusi, Kontak Rumah Sakit rujukan covid-19, dan logout. User dapat mulai mengisi gejala yang di alami pada menu Input Gejala, dan mengikuti langkah selanjutnya.

Proses kerja untuk admin dengan diawali login dan admin akan masuk ke halaman utama yang berisi gejala, pada halaman tersebut admin dapat langsung menambah, menghapus, mengubah gejala yang ada.

Untuk lebih jelas mengenai sistem kerja pada sistem ini dapat dilihat pada gambar 1 untuk sistem kerja user, dan gambar 2 untuk sistem kerja admin.

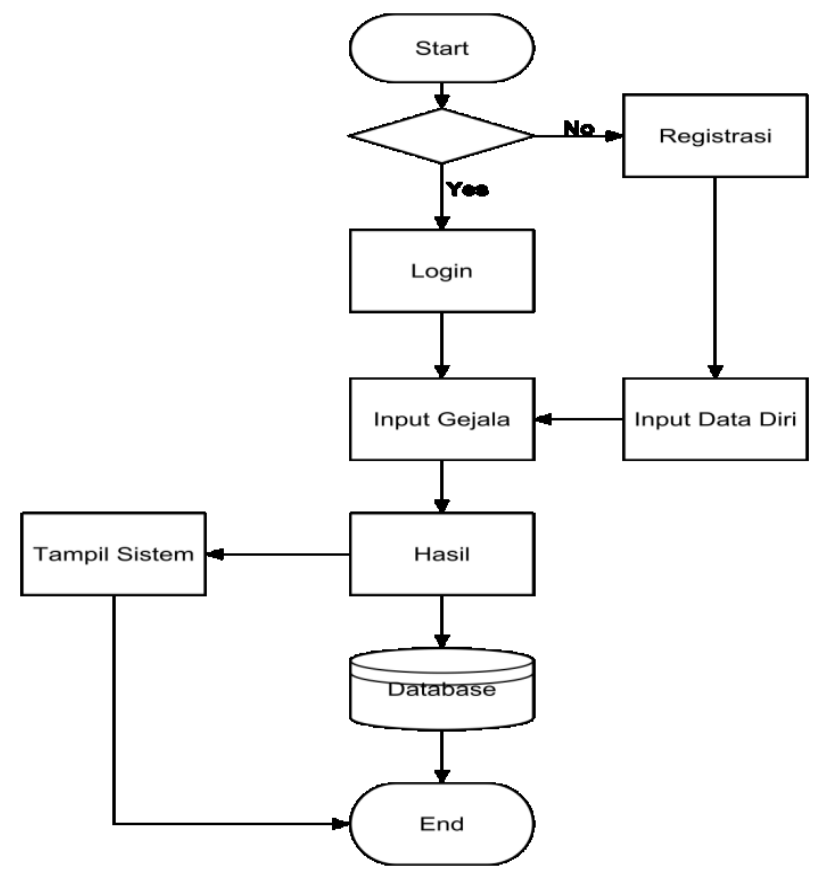

Gambar 1. Flowchart User

Gambar diatas menjelaskan tentang alur user dalam menggunakan sistem untuk deteksi awal covid-19, sebelum menggunakan sistem ini user harus memiliki akun terlebih dahulu dan login pada akunnya, setelah berhasil login, user dapat menginput gejala yang dirasakannya, data gejala yang diinputkan oleh user ini 
selanjutnya akan disimpan pada database sistem untuk selanjutnya dijadikan rekap medis, setelah melakukan input gejala, user dapat melihat hasilnya serta dapat mengunduh dan mencetak hasil output yang dikeluarkan sistem nantinya hasil tersebut dapat dibawa ke Rumah Sakit untuk dilakukan pemeriksaan lebih lanjut.

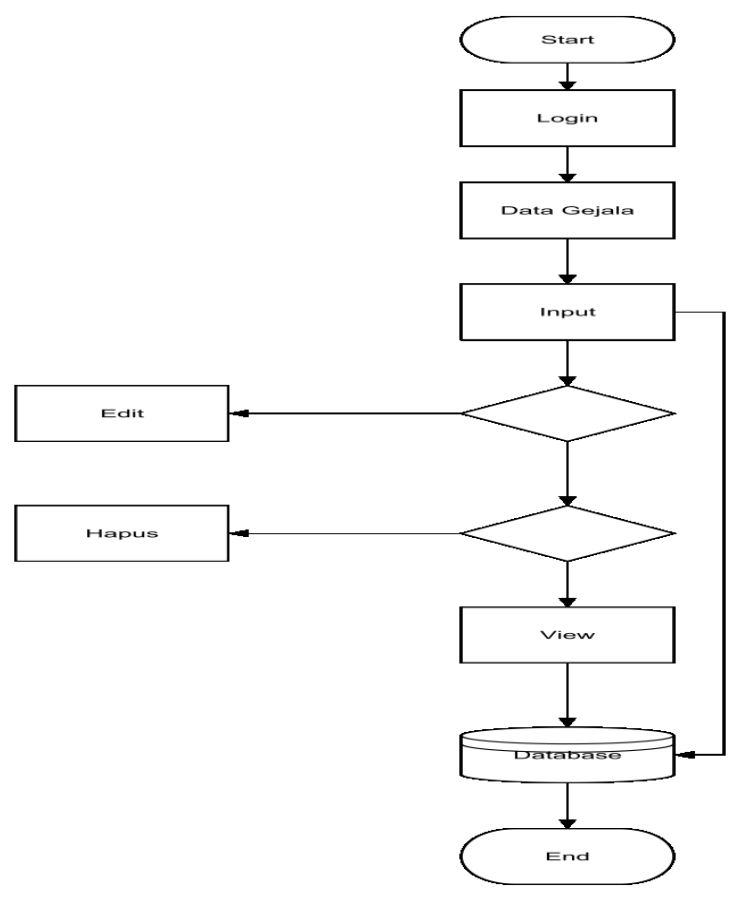

Gambar 2. Flowchart Admin

Pada gambar 2 merupakan alur admin yang dapat menjalankan seluruh fitur yang ada dalam sistem, setelah login admin dapat melakukan tugasnya seperti melihat data gejala yang sudah ada, melakukan input gejala, edit gejala dan hapus gejala yang sudah ada sehingga semua proses tersebut nantinya akan di simpan dalam database sistem ini yang menggunakn SQL.

\section{Hasil dan Pembahasan}

Adapun hasil dan pembahasan metode certainty factor pada sistem pakar ini adalah menggunakan metode certainty factor untuk mengukur nilai ketidakpastian dan mengubahnya menjadi suatu nilai yang pasti dengan mengambil nilai kepastian dari seorang pakar terhadap suatu aturan dan mengatasi kesulitan dalam menentukan gejala-gejala pada sistem deteksi awal covid-19.

Hasil penelitian dan juga pembahasan dari Sistem Pakar dengan metode certainty factor untuk melakukan deteksi awal terhadap covid-19 adalah sebagai berikut :

Melakukan pembobotan pada tiap pilihan, dapat dilihat pada tabel 3.1 sebelum melakukan diagnosa covid-19 dengan certainty factor, dibutuhkan pembobotan pilihan untuk menentukan tingkat gejala yang dialami, sehingga setiap gejala diketahui bobotnya serta dapat melakukan perhitungan dengan akurat.

Tabel 3.1. Menentukan Bobot Pilihan

\begin{tabular}{lll}
\hline No & \multicolumn{1}{c}{ Pilihan } & \multicolumn{1}{c}{ Bobot } \\
\hline 1 & Tidak & 0 \\
2 & Tidak Tahu & 0,2 \\
3 & Mungkin & 0,4 \\
4 & Kemungkinan Besar & 0,6 \\
5 & Hampir Pasti & 0,8 \\
6 & Pasti & 1
\end{tabular}

Tabel ini berfungsi untuk menentukan bobot dari tiap pilihan, sehingga saat user melakukan input gejala diketahui bobotnya.

Menentukan Hipotesa Gejala Covid-19 pada tabel 3.2 menentukan pembobotan tiap gejala berdasarkan pakar. Gejala yang dimasukkan merupakan gejala dari seorang pakar serta hipotesa yang diberikan juga 
merupakan hipotesa dari seorang pakar. dengan tingkat kepercayaan yang telah ditentukan oleh pakar terhadap gejala-gejala yang mempengaruhi probabilitas terjadinya suatu gejala covid-19.

Tabel 3.2. Hipotesa Gejala Covid-19

\begin{tabular}{|c|c|c|c|}
\hline No & $\begin{array}{l}\text { Kode } \\
\text { Gejala }\end{array}$ & Nama Gejala & Hipotesa \\
\hline 1 & G01 & $\begin{array}{l}\text { Demam (Suhu Diatas } \\
38^{\circ} \mathrm{C}\end{array}$ & 0,8 \\
\hline 2 & $\mathrm{G} 02$ & Nyeri Telan & 0,6 \\
\hline 3 & G03 & Batuk Kering & 0,4 \\
\hline 4 & G04 & Sesak Nafas & 1 \\
\hline 5 & G05 & $\begin{array}{l}\text { Pernah Melakukan Kontak } \\
\text { Dengan Penderita Covid- } \\
19\end{array}$ & 0,8 \\
\hline 6 & G06 & $\begin{array}{l}\text { Keluar Rumah Tanpa } \\
\text { Menggunakan Masker }\end{array}$ & 0,6 \\
\hline
\end{tabular}

Tabel ini menunjukan Gejala yang ada dengan bobot gejala yang di dapat dari pakar, pakar memberikan skala nilai bobot untuk tiap gejala antara $0-1$.

Nilai 0 menentukan bahwa user meng informasikan tidak mengalami gejala seperti yang ditanyakan oleh sistem. Semakin user yakin bahwa gejala tersebut memang dialami olehnya. Proses dalam perhitungan premis majemuk dan akan menjadi kaidah-kaidah yang memiliki premis tunggal. Kemudian masing - masing aturan baru dihitung dengan Certainty Factor-nya, sehingga diperoleh dengan nilai Certainty Factor, untuk masing-masing aturan. Kemudian Certainty Factor di kombinasi kan Sebagai contoh, proses pemberian bobot pada setiap premis (gejala) hingga diperoleh persentase keyakinan untuk diagnosa covid-19.

Pakar menentukan nilai CF untuk masing-masing gejala sebagai berikut:

$\begin{array}{ll}\left.\text { CF pakar (Demam, Diatas } 38^{\circ} \mathrm{C}\right) & =0.8 \\ \text { CF pakar (Nyeri Telan ) } & =0.6 \\ \text { CF pakar (Batuk Kering) } & =0.4 \\ \text { CF pakar (Sesak Nafas) } & =1 \\ \text { CF pakar (Kontak dengan penderita covid-19) } & =0.8 \\ \text { CF pakar (Keluar rumah tanpa masker) } & =0.6\end{array}$

Proses pembobotan pada setiap premis untuk mendapatkan persentase kepercayaan untuk melakukan deteksi awal covid-19.

Tabel 3.3. Presentase Nilai Kepercayaan

\begin{tabular}{ll}
\hline Presentasi & Nilai Kepercayaan \\
\hline $0 \%-40 \%$ & Negatif \\
$41 \%-85 \%$ & Kemungkinan Besar \\
$86 \%-100 \%$ & Positif \\
\hline
\end{tabular}

Penerapan metode CF pada sistem pakar memerlukan beberapa rule berupa variabel gejala dan nilai bobot yang diberikan oleh pakar. Rule CF yang berisi gejala dan nilai bobot dari pakar untuk setiap gejala. Nilai Certainty Factor ditentukan untuk setiap gejala yang melekat pada suatu penyakit dan dalam sistem ini nilai certainty factor dapat diupdate. Dari gejala yang diinputkan oleh user, maka dapat dibentuk 3 aturan (rule) Sebagai berikut :

Rule 1: IF Demam Hampir Pasti AND Nyeri Telan Mungkin AND Batuk Kering Mungkin AND Sesak Nafas Kemungkinan Besar AND Kontak dengan penderita Covid-19 Tidak AND Keluar rumah tanpa menggunakan masker Pasti.

Rule 2 : IF Demam Tidak Tahu AND Nyeri Telan Mungkin AND Batuk Kering Tidak AND Sesak Nafas Tidak AND Kontak dengan penderita Covid-19 Tidak AND Keluar rumah tanpa menggunakan masker Tidak.

Rule 3 : IF Demam Tidak AND Nyeri Telan Tidak AND Batuk Kering Tidak Tahu AND Sesak Nafas Tidak Tahu AND Kontak dengan penderita Covid-19 Pasti AND Keluar rumah tanpa menggunakan masker Pasti. 
Perhitungan dibutuhkan untuk mengetahui langkah dan hasil dalam penelitian ini, maka dibutuhkan perhitungan yang dapat membantu dalam memberikan diagnosa covid-19. Metode perhitungan pada sistem dalam penelitian ini menggunakan metode Certainty Factor. Langkah pertama penggunaan metode Certainty Factor dalam proses perhitungan berdasarkan gejala-gejala yang telah diinputkan oleh user adalah dengan mengalikan 2 nilai bobot yaitu CF user dan CF pakar. Langkah selanjutnya adalah kombinasi hasil perkalian setiap gejala yang telah dikalikan. Kombinasi hanya dapat dilakukan pada 2 nilai CF. Pembobotan nilai maksimum pada penelitian ini adalah 1. Berdasarkan hasil akhir kombinasi dapat diketahui diagnosa yang dikeluarkan sistem dengan berupa nilai keyakinan dari setiap aturan (rule), berikutnya adalah mengubah nilai keyakinan menjadi nilai persentase sehingga di dapat presentase keyakinan sebagai diagnosa akhir pada sistem.

Perhitungan rule 1 dengan mengalikan $\mathrm{CF}$ user dan $\mathrm{CF}$ pakar.

Rule 1:

$$
\begin{array}{rl}
C F[H, E]_{1}=C F[H]_{1} * C & F[E]_{1} \\
& =0.8 * 0.8 \\
& =0.64 \\
C F[H, E]_{2}=C F[H]_{2} * C F & {[E]_{2}} \\
& =0.6 * 0.4 \\
& =0.24 \\
C F[H, E]_{3}=C F[H]_{3} * C & {[E]_{3}} \\
& =0.4 * 0.4 \\
& =0.16 \\
C F[H, E]_{4}=C F[H]_{4} * C & {[E]_{4}} \\
& =1 * 0.6 \\
& =0.6 \\
C F & {[E]_{5}} \\
& =0.8 * 0 \\
& =0 \\
C F[H, E]_{5}=C F[H]_{5} * & \\
C F[E] 6 \\
=
\end{array}
$$

Langkah selanjutnya adalah melakukan CF combine dari masing - masing nilai CF pada rule 1 .

Rule 1 :

$$
\begin{aligned}
& C F_{\text {combine }} C F[H, E]_{1,2}=C F[H, E]_{1}+C F[H, E]_{2} *\left(1-C F[H, E]_{1}\right) \\
& =0.16+0.24 *(1-0.64)=0.64+0.24 *(0.36) \\
& =0.64+0.08=0.72_{\text {old }} \\
& C F_{\text {combine }} C F[H, E]_{\text {old }, 3}=C F[H, E]_{\text {old }}+C F[H, E]_{3} *\left(1-C F[H, E]_{\text {old }}\right) \\
& =0.72+0.16 *(1-0.72)=0.72+0.16 *(0.28) \\
& =0.72+0.04=0.76 \text { old } 2 \\
& C F_{\text {combine }} C F[H, E]_{\text {old } 2,4}=C F[H, E]_{\text {old } 2}+C F[H, E]_{4} *\left(1-C F[H, E]_{\text {old } 2}\right) \\
& =0.76+0.6 *(1-0.76)=0.76+0.6 *(0.24) \\
& =0.76+0.14=0.9 \text { old } 3 \\
& C F_{\text {combine }} C F[H, E]_{\text {old } 3,5}=C F[H, E]_{\text {old } 3}+C F[H, E]_{5} *\left(1-C F[H, E]_{\text {old } 3}\right) \\
& =0.9+0 *(1-0.9)=0.9+0 *(0.1) \\
& =0.9+0=0.9 \text { old } 4 \\
& C F_{\text {combine }} C F[H, E]_{\text {old } 4,6}=C F[H, E]_{\text {old } 4}+C F[H, E]_{6} *\left(1-C F[H, E]_{\text {old } 4}\right) \\
& =0.9+0.6 *(1-0.9)=0.9+0.6 *(0.1) \\
& =0.9+0.06=0.96 \text { old } 5
\end{aligned}
$$


Setelah melakukan CF combine selanjutnya melakukan persentase nilai $\mathrm{CF}$

$C F=C F_{\text {old } 5} * 100 \%$

$\mathrm{CF}=0.96 * 100 \%$

$\mathrm{CF}=96 \%$

Dengan demikian dapat disimpulkan bahwa deteksi awal covid-19 pada rule 1 menggunakan metode Certainty Factor memiliki presentase keyakinan 96\%.

Selanjutnya melakukan perhitungan pada rule 2 dengan menggunakan kaidah yang telah diinput oleh user, dan dengan mengalikan CF user dan CF pakar

Rule 2 :

$$
\begin{aligned}
& C F[H, E]_{1}=C F[H]_{1} * C F[E]_{1} \\
& =0.8 * 0.2 \\
& =0.16 \\
& \mathrm{CF}[\mathrm{H}, \mathrm{E}]_{2}=\mathrm{CF}[\mathrm{H}]_{2} * \mathrm{CF}[\mathrm{E}]_{2} \\
& =0.6 * 0.4 \\
& =0.24 \\
& \mathrm{CF}[\mathrm{H}, \mathrm{E}]_{3}=\mathrm{CF}[\mathrm{H}]_{3} * \mathrm{CF}[\mathrm{E}]_{3} \\
& =0.4 * 0 \\
& =0 \\
& \mathrm{CF}[\mathrm{H}, \mathrm{E}]_{4}=\mathrm{CF}[\mathrm{H}]_{4} * \mathrm{CF}[\mathrm{E}]_{4} \\
& =1 * 0 \\
& =0 \\
& \mathrm{CF}[\mathrm{H}, \mathrm{E}]_{5}=\mathrm{CF}[\mathrm{H}]{ }_{5} * \mathrm{CF}[\mathrm{E}] 5 \\
& =0.8 * 0 \\
& =0 \\
& \mathrm{CF}[\mathrm{H}, \mathrm{E}]_{6}=\mathrm{CF}[\mathrm{H}]_{6} * \mathrm{CF}[\mathrm{E}]_{6} \\
& =0.6 * 0 \\
& =0
\end{aligned}
$$

Langkah selanjutnya adalah melakukan CF combine dari masing - masing nilai CF.

Rule 2 :

$$
\begin{aligned}
& C F_{\text {combine }} C F[H, E]_{1,2}=C F[H, E]_{1}+C F[H, E]_{2} *\left(1-C F[H, E]_{1}\right) \\
& =0.16+0.24 *(1-0.16)=0.16+0.24 *(0.84) \\
& =0.16+0.20=0.36 \text { old } \\
& C F_{\text {combine }} C F[H, E]_{\text {old }, 3}=C F[H, E]_{\text {old }}+C F[H, E]_{3} *\left(1-C F[H, E]_{\text {old }}\right) \\
& =0.36+0 *(1-0.36)=0.36+0 *(0.64) \\
& =0.36+0=0.36 \text { old } 2 \\
& C F_{\text {combine }} C F[H, E]_{\text {old } 2,4}=C F[H, E]_{\text {old } 2}+C F[H, E]_{4} *\left(1-C F[H, E]_{\text {old } 2}\right) \\
& =0.36+0 *(1-0.36)=0.36+0 *(0.64) \\
& =0.36+0=0.36 \text { old } 3 \\
& C F_{\text {combine }} C F[H, E]_{\text {old } 3,5}=C F[H, E]_{\text {old } 3}+C F[H, E]_{5} *\left(1-C F[H, E]_{\text {old } 3}\right) \\
& =0.36+0 *(1-0.36)=0.36+0 *(0.64) \\
& =0.36+0=0.36 \text { old } 4 \\
& C F_{\text {combine }} C F[H, E]_{\text {old } 4,6}=C F[H, E]_{\text {old } 4}+C F[H, E]_{6} *\left(1-C F[H, E]_{\text {old } 4}\right) \\
& =0.36+0 *(1-0.36)=0.36+0 *(0.64) \\
& =0.36+0=0.36 \text { old } 5
\end{aligned}
$$


Setelah melakukan $\mathrm{CF}$ combine selanjutnya melakukan persentase nilai $\mathrm{CF}$

$$
\begin{aligned}
& C F=C F_{\text {old } 5} * 100 \% \\
& \mathrm{CF}=0.36 * 100 \% \\
& \mathrm{CF}=36 \%
\end{aligned}
$$

Dengan demikian dapat disimpulkan bahwa deteksi awal covid-19 menggunakan metode Certainty Factor memiliki presentase keyakinan $36 \%$.

Selanjutnya melakukan perhitungan pada rule 3 dengan menggunakan kaidah yang telah diinput oleh user, dan dengan mengalikan CF user dan CF pakar

Rule 3 :

$$
\begin{aligned}
& C F[H, E]_{1}=C F[H]_{1} * C F[E]_{1} \\
& =0.8 * 0 \\
& =0 \\
& \mathrm{CF}[\mathrm{H}, \mathrm{E}]_{2}=\mathrm{CF}[\mathrm{H}]_{2} * \mathrm{CF}[\mathrm{E}]_{2} \\
& =0.6 * 0 \\
& =0 \\
& \mathrm{CF}[\mathrm{H}, \mathrm{E}]_{3}=\mathrm{CF}[\mathrm{H}]_{3} * \mathrm{CF}[\mathrm{E}]_{3} \\
& =0.4 * 0.2 \\
& =0.08 \\
& \mathrm{CF}[\mathrm{H}, \mathrm{E}]_{4}=\mathrm{CF}[\mathrm{H}]_{4} * \mathrm{CF}[\mathrm{E}]_{4} \\
& =1 * 0.2 \\
& =0.2 \\
& \mathrm{CF}[\mathrm{H}, \mathrm{E}]_{5}=\mathrm{CF}[\mathrm{H}]_{5} * \mathrm{CF}[\mathrm{E}]_{5} \\
& =0.8 * 1 \\
& =0.8 \\
& =0.6 * 1 \\
& =0.6
\end{aligned}
$$

Langkah selanjutnya adalah melakukan CF combine dari masing - masing nilai CF. Rule 3 :

$$
\begin{aligned}
& C F_{\text {combine }} C F[H, E]_{1,2}=C F[H, E]_{1}+C F[H, E]_{2} *\left(1-C F[H, E]_{1}\right) \\
& =0+0 *(1-0)=0+0 *(1) \\
& =0+0=0 \text { old } \\
& C F_{\text {combine }} C F[H, E]_{\text {old }, 3}=C F[H, E]_{\text {old }}+C F[H, E]_{3} *\left(1-C F[H, E]_{\text {old }}\right) \\
& =0+0.08 *(1-0)=0+0.08 *(1) \\
& =0+0.08=0.08 \text { old } 2 \\
& C F_{\text {combine }} C F[H, E]_{\text {old } 2,4}=C F[H, E]_{\text {old } 2}+C F[H, E]_{4} *\left(1-C F[H, E]_{\text {old } 2}\right) \\
& =0.08+0.2 *(1-0.08)=0.08+0.2 *(0.92) \\
& =0.08+0.18=0.26 \text { old } 3 \\
& C F_{\text {combine }} C F[H, E]_{\text {old } 3,5}=C F[H, E]_{\text {old } 3}+C F[H, E]_{5} *\left(1-C F[H, E]_{\text {old } 3}\right) \\
& =0.26+0.5 *(1-0.26)=0.26+0.5 *(0.74) \\
& =0.26+0.37=0.63 \text { old } 4 \\
& C F_{\text {combine }} C F[H, E]_{\text {old } 4,6}=C F[H, E]_{\text {old } 4}+C F[H, E]_{6} *\left(1-C F[H, E]_{\text {old } 4}\right) \\
& =0.63+0.6 *(1-0.63)=0.63+0.6 *(0.37) \\
& =0.63+0.22=0.85 \text { old } 5
\end{aligned}
$$


Setelah melakukan CF combine selanjutnya melakukan persentase nilai $\mathrm{CF}$

$C F=C F_{\text {old } 5} * 100 \%$

$\mathrm{CF}=0.85 * 100 \%$

$\mathrm{CF}=85 \%$

Dengan demikian dapat disimpulkan bahwa deteksi awal covid-19 menggunakan metode Certainty Factor memiliki presentase keyakinan $85 \%$.

Pada Bab Hasil dan Pembahasan dapat diketahui bahwa pembobotan gejala yang ada dapat dengan tepat dilakukan perhitungan gejala pada certainty factor. Setelah melakukan perhitungan terhadap 3 Rule dengan menggunakan metode Certainty Factor di dapat hasil sebagai berikut :

Tabel 3.4. Diagnosa Tiap Rule

\begin{tabular}{lll}
\hline Rule & Presentase Keyakinan & Diagnosa Sistem \\
\hline Rule 1 & $96 \%$ & Positif \\
\hline Rule 2 & $36 \%$ & Negatif \\
\hline Rule 3 & $85 \%$ & Kemungkinan Besar \\
\hline
\end{tabular}

Pada tabel ini dapat diketahui hasil tiap rule sebagai berikut :

a. Rule 1, setelah user melakukan input gejala pada sistem dan sistem melakukan perhitungan, didapatkan hasil persentase keyakinan sebesar $96 \%$ sehingga sistem dapat mendiagnosa user memiliki kecenderungan Positif Covid-19.

b. Rule 2, setelah user melakukan input gejala pada sistem dan sistem melakukanperhitungan, didapatkan hasil persentase keyakinan sebesar $36 \%$ sehingga sistem dapat mendiagnosa user memiliki kecenderungan Negatif Covid-19.

c. Rule 3, setelah user melakukan input gejala pada sistem dan sistem melakukan perhitungan, didapatkan hasil persentase keyakinan sebesar $85 \%$ sehingga sistem dapat mendiagnosa user memiliki kecenderungan Kemungkinan Besar Covid-19.

\section{KESIMPULAN}

Wabah Covid-19 tidak hanya merupakan masalah nasional dalam suatu negara, tapi sudah merupakan sebuah masalah global, virus ini sangat cepat menular antar droplet hanya dengan melakukan kontak fisik, virus ini sulit dideteksi gejalanya karena memiliki gejala yang mirip dengan beberapa penyakit lainnya. Untuk dapat mendiagnosa pasien yang memiliki gejala covid-19 diperlukan melakukan 2 test yaitu rapid dan swab test yang tentu saja harganya tidak murah.

Hal ini membuat beberapa masyarakat kalangan menengah ke bawah kesulitan untuk melakukan rapid maupun swab test sehingga penanganan medis menjadi terlambat dan dapat mengakibatkan resiko kematian. Pada penelitian ini peneliti membuat sebuah sistem pakar untuk melakukan deteksi awal terhadap gejala covid19. Sistem deteksi awal Covid-19 menggunakan metode certainty factor sebagai penentu faktor kepastian, dan akan menghasilkan presentase keyakinan sebagai output sistem. Yang nantinya diharapkan masyarakat dapat melakukan diagnosa mandiri di rumah masing-masing menggunakan sistem ini, dan juga paramedis dapat menggunakan sistem ini untuk melakukan deteksi awal terhadap pasien yang ter-indikasi terjangkit covid-19, sehingga pada akhirnya sistem ini dapat membantu semua pihak dalam menangani covid-19 serta mencegah penyebarannya.

Pengembangan sistem pakar deteksi awal covid-19 dilakukan melalui beberapa hal tahapan perancangan sistem dengan tujuan untuk memberikan gambaran umum tentang apa saja gejala yang ditimbulkan oleh covid-19. Setiap gejala diberi bobot untuk menghitung nilai CF-nya, lalu dilakukan perhitungan CF-nya dengan menggunakan pembobotan pada setiap gejala yang ada dan dengan menggunakan hipotesa dari seorang pakar juga Evidence dari kondisi setiap user yang membentuk sebuah aturan (rule) menggunakan perhitungan certainty factor sehingga dihasilkan sebuah sistem yang dapat melakukan deteksi awal covid-19.

Dari hasil 3 rule perhitungan sistem diperoleh hasil sebagai berikut rule 1 dinyatakan $96 \%$ sehingga sistem dapat mendiagnosa bahwa user pada rule 1 positif covid-19, rule $236 \%$ sehingga sistem dapat 
mendiagnosa bahwa user pada rule 2 Negatif covid-19, dan rule $385 \%$ sehingga sistem dapat mendiagnosa bahwa user pada rule 3 kemungkinan besar terinfeksi covid-19.

Dengan hasil presentase keyakinan yang dihasilkan oleh sistem pada setiap rule, dapat dilihat bahwa presentase keyakinan pada setiap rule berbanding lurus dengan gejala yang diinputkan tiap user, maka dapat disimpulkan bahwa sistem ini dapat melakukan perhitungan secara akurat, serta dapat melakukan diagnosa dengan baik.

Deteksi awal Covid-19 menggunakan metode Certainty Factor terbukti berhasil menghitung faktor keyakinan untuk mendapatkan hasil diagnosa. Dengan menggunakan metode ini, diagnosa dapat dilakukan dengan hasil persentase keyakinan yang dapat digunakan sebagai diagnosa awal.

Sistem ini dapat dikembangkan lebih baik dengan menerapkan beberapa metode atau menambahkan konsep keputusan sistem pakar sehingga pengguna dapat mengetahui langkah atau solusi yang tepat untuk penyakit atau gejala yang ditimbulkan. Diharapkan sistem ini dikembangkan untuk kasus lainnya dengan objek yang berbeda sehingga dapat menambah wawasan serta dapat mempermudah orang lain.

\section{REFERENCES}

[1] F. WU, S. ZHAO, B. YU, “A new coronavirus associated with human respiratory disease in China.,” Nat. , vol. 579 (7798), p. p.265-269, 2020.

[2] B. Etikasari, T. D. Puspitasari, A. A. Kurniasari, and L. Perdanasari, "Sistem informasi deteksi dini Covid-19," J. Tek. Elektro dan Komput., vol. 9, no. 2, pp. 101-108, 2020.

[3] S. Syafrida, "Bersama Melawan Virus Covid 19 di Indonesia," SALAM J. Sos. dan Budaya Syar-i, vol. 7, no. 6, 2020, doi: 10.15408/sjsbs.v7i6.15325.

[4] J. Moudy and R. A. Syakurah, "Pengetahuan terkait usaha pencegahan Coronavirus Disease (COVID-19) di Indonesia," Higeia J. Public Heal. Res. Dev., vol. 4, no. 3, pp. 333-346, 2020.

[5] A. Bernheim et al., "Chest CT findings of coronavirus disease 2019 (COVID-19)," J. Coll. Physicians Surg. Pakistan, vol. 295, no. 3, pp. 685-691, 2020.

[6] N. Yudistira, A. W. Widodo, and B. Rahayudi, "Deteksi Covid-19 pada Citra Sinar-X Dada Menggunakan Deep Learning yang Efisien," J. Teknol. Inf. dan Ilmu Komput., vol. 7, no. 6, p. 1289, 2020, doi: 10.25126/jtiik.2020763651.

[7] W. U. Setiabudi, E. Sugiharti, and F. Y. Arini, "Expert System Diagnosis Dental Disease Using Certainty Factor Method," Sci. J. Informatics, vol. 4, no. 1, pp. 43-50, 2017, doi: 10.15294/sji.v4i1.8463.

[8] A. T. Septyanto and I. H. Al Amin, "Expert System for Diagnosing Newborn Babies Disease Using the Sorgenfrei Similarity Method," J. Appl. Informatics ..., vol. 4, no. 2, 2020, [Online]. Available: https://jurnal.polibatam.ac.id/index.php/JAIC/article/view/2192.

[9] A. Ramdhani, R. R. Isnanto, and I. P. Windasari, "Pengembangan Sistem Pakar Untuk Diagnosis Penyakit Hepatitis Berbasis Web Menggunakan Metode Certainty Factor," J. Teknol. dan Sist. Komput., vol. 3, no. 1, p. 58, 2015, doi: 10.14710/jtsiskom.3.1.2015.58-64.

[10] K. Anggriani, D. Andreswari, and S. R. Sihite, “Aplikasi Diagnosa Sementara Penyakit Anak Bawah Lima Tahun (Balita) Kawasan Pesisir Kota Bengkulu Menggunakan Metode Certainty Factor (Transient Diagnosis App to Detect Diseases in Children Under Five Years of Age in Bengkulu Coastal Area Using Certainty ," J. IPTEKKOM J. Ilmu Pengetah. Teknol. Inf., vol. 20, no. 1, p. 61, 2018, doi: 10.33164/iptekkom.20.1.2018.61-76.

[11] A. Pakpahan et al., "Implementation of Certainty Factor Method for Diagnoses of Photocopy Machine Damage," J. Phys. Conf. Ser., vol. 1255, no. 1, 2019, doi: 10.1088/1742-6596/1255/1/012059.

[12] A. S. Sembiring et al., "Implementation of Certainty Factor Method for Expert System," J. Phys. Conf. Ser., vol. 1255, no. 1, 2019, doi: 10.1088/1742-6596/1255/1/012065.

[13] F. Agus, H. E. Wulandari, and I. F. Astuti, "Expert System With Certainty Factor For Early Diagnosis Of Red Chili Peppers Diseases," J. Appl. Intell. Syst., vol. 2, no. 2, pp. 52-66, 2018, doi: 10.33633/jais.v2i2.1455.

[14] E. A. Feigenbaum, "Expert Systems: Principles and Practice,” Encycl. Comput. Sci. Engneering, vol. 581, pp. 1-12, 1992, [Online]. Available: http://citeseerx.ist.psu.edu/viewdoc/summary?doi=10.1.1.34.9207. 
